\title{
Current state of orthodontic patients under Bisphosphonate therapy
}

\author{
Elena Krieger ${ }^{1 *}$, Collin Jacobs ${ }^{1}$, Christian Walter ${ }^{2}$ and Heinrich Wehrbein ${ }^{1}$
}

\begin{abstract}
Background: Bisphosphonates are a common medication for the prevention and therapy of osteoporosis, but are also applied for tumor diseases. They affect bone metabolism, and therefore also orthodontic treatments, but how it does has yet not been definitively clarified. Therefore, the aim of this research was to evaluate and demonstrate the reported effects and the current state of scientific research regarding orthodontic treatment and bisphosphonate medication exclusively in humans.

Material and methods: A systematic research of the literature for selected keywords in the Medline database (Pubmed) as well as a manual search was conducted. The following search terms were used: 'Bisphosphonate' in combination with: orthodontic, orthodontic treatment, tooth movement.

Findings: To date, only nine reported patients (case reports/series) and one original article (retrospective cohort study) regarding orthodontic treatment under bisphosphonate medication in humans have been published. Decelerated tooth movement with increased side effects (especially in high-risk patients) and longer treatment duration was reported in some articles. Patients with initial spacing or extraction cases had a higher risk of incomplete space closure and poor root parallelism.

Conclusions: Orthodontic tooth movement under bisphosphonate medication is possible, especially in low-risk patients (low dose and short period of intake). But the treatment is still not predictable, especially in high-risk patients. Therefore, the altered bone metabolism and higher extent of side effects should be considered in treatment planning, especially in extraction cases or high-risk patients. Regardless, longer treatment duration, decelerated tooth movement, and more side effects, e.g., incomplete space closure and poor root parallelism, should be expected, especially in extraction cases or space closure.
\end{abstract}

Keywords: Medication, Side effects, Bone metabolism, Orthodontic treatment, Tooth movement

\section{Introduction}

Bisphosphonates (BPs) are used in patients with metabolic bone diseases such as osteoporosis and in patients with malignomas and metastases to the bone. They have an inhibiting effect on osteoclastic activity and therefore decrease the bone resorption. The half-life can be more than 10 years [1]. One side effect is a bisphosphonate associated osteonecrosis of the jaws (BP-ONJ) [2-8]. The risk of $\mathrm{BP}-\mathrm{ONJ}$ seems to depend on the type of BP, dose, duration and application form (intravenous or oral). Patients with IV $\mathrm{BP}$ and malignant disease are at a higher risk compared to patients with oral BP and benign diseases [2-8].

\footnotetext{
* Correspondence: elena.krieger@unimedizin-mainz.de

1 Department of Orthodontics, Medical Centre of the Johannes-

Gutenberg-University Mainz, Augustusplatz 2, 55131, Mainz, Germany

Full list of author information is available at the end of the article
}

To date, the altered bone metabolism and the following consequences to orthodontic therapy and, possibly, revised indications have not been clarified. Only statements regarding dentosurgical therapies have been published by the field societies [5-7]. Concerning orthodontic aspects, there are no guiding principles.

Therefore, the aim of this study was to analyze the literature reporting on the combination of orthodontic treatment and BP medication exclusively in humans.

\section{Material and methods}

A systematic research in PubMed was performed covering publications from Jan 2000- Jan 2013. In conjunction with this, a manual search of national professional orthodontic journals published in German but not listed in PubMed 
was conducted. In addition, the citations in identified articles were analyzed as well. Inclusion criteria were reports on humans, BP treatment, and orthodontic treatment. Exclusion criteria were reports on animals, and a lack of BP and/or orthodontic treatment. The following search terms were used:

'Bisphosphonate' in combination with: orthodontic, orthodontic treatment, tooth movement.

\section{Results}

Altogether, without redundancies, 28 articles were found. Only seven articles met the inclusion criteria: four case reports [9-12], two case series with two [13] and three patients respectively [14], and one original article with 20 BP medicated patients [15].

The original article presented a retrospective cohort study with women $<50$ years-of-age [15]. The study was approved by the institutional review board at the University of Washington in Seattle. Orthodontists from the USA were invited to perform case reviews of their patients regarding women $<50$ years-of-age. The sample comprised 113 female patients, divided into two groups, one with $(\mathrm{n}=20$; 19 with oral BP, 1 with IV BP) and one without $(n=93)$ BP treatment. BP patients that were treated orthodontically with extractions and space closing had to be treated significantly longer, and they had a higher risk of incomplete space closure and poor root parallelism at the end of treatment. No BP-ONJ was described. Both groups had an alignment of the incisors of less than $1 \mathrm{~mm}$ discrepancy.

The following is a summary of the nine reported patients on BP with orthodontic treatment (Table 1) [9-14]:

1. A 35-year-old middle to high-risk female patient on oral alendronate and corticosteroids due to Addison's disease underwent orthodontic treatment lasting 30 months. Orthodontic space closing and root paralyzing was described as difficult and tooth movement decelerated. An orthopantomogram at the end of the treatment showed radiopaque areas, sclerotic lines, and denser bone. Widened periodontal ligaments (PDL) were only found at the extraction site. Further orthopantomograms 20 months after treatment and 12 months after discontinuing BP treatment revealed no more sclerotic areas of bone and no apical root resorption [13].

2. A 77-year-old high-risk male patient with sacral plasmocytoma with radiation, chemotherapy, and IV BP (zoledronate) had orthodontic space closure after extraction of the lingually-positioned tooth 42 (residual gap of $2 \mathrm{~mm}$ ). After developing multiple myeloma, BP-ONJ developed in the right mandible, and orthodontic treatment was stopped at month 13. Instead of bodily movement, only tipping of the crowns had occurred and the tooth movement was slowed [13].

3. A 60-year-old low-risk female patient (oral alendronate for 18 months) with osteoporosis had a severe right posterior open bite which was scheduled to be closed orthodontically. Before starting the treatment, a mild sclerosis was observed at tooth 47. Two years later sclerotic bone occurred around the treated teeth with a widened PDL. BP was stopped after 3.5 years in total. The radiographic signs were enhanced and tooth movement was decelerated so that orthodontic treatment was discontinued after 4.5 years. No apical root resorption occurred [14].

4. A 50-year-old low-risk female patient underwent space closing after periodontal treatment and extraction of tooth 34. Alendronate intake due to osteoporosis was not known by the orthodontist. BP treatment was stopped after 12 months because of esophagitis (common side effect of BP). In 19 months of treatment, only crown-tipping occurred instead of bodily movement, and tooth movement was slowed down. Hypermineralized areas were found at the extraction site. Even 13 months after stopping BP and completion of further orthodontic treatment, extensive mobility and widened PDL were observed [14].

5. A 74-year-old low-risk female patient with 36 months of oral alendronate use (for osteoporosis) and severe bone loss because of periodontal disease had tooth 31 extracted with orthodontic space closure. BP treatment was stopped 3 months prior to orthodontic treatment, which took 14 months. On initial radiographs mild sclerosis around the mandibular molars and obscured anterior PDL gaps were diagnosed. The final radiographs showed mild sclerotic and PDL spaces, mild apical root resorption of mandibular incisor, and no increased mobility. Space closure and alignment were considered successful [14].

6. A 68-year-old low-risk female patient taking oral ibandronate for osteoporosis had an augmentation of the right sinus with autologous particulated bone from the anterior mandible. For skeletal anchorage a rigid fixation plate was inserted at the os zygomaticum. After 6 months of healing, teeth 13, 14 , and 15 were distalized using the bone anchor, and all teeth were aligned (duration: 26 weeks). After distalization, all teeth were orthodontically aligned and dental implants inserted in the posterior right maxilla. The overall duration of orthodontic treatment was not specified, and no complications related to the BP medication were observed [9].

7. "Bloodless tooth extraction" after orthodontic extrusion was performed in a 70-year-old low-risk 
Table 1 Presentation of the nine reported cases of orthodontically treated patients under BP medication [9-14]

\begin{tabular}{|c|c|c|c|c|c|c|c|c|c|}
\hline & Case 1 [13] & Case 2 [13] & Case 3 [14] & Case 4 [14] & Case 5 [14] & Case 6 [9] & Case 7 [10] & Case 8 [11] & Case 9 [12] \\
\hline Anamnesis & $\begin{array}{l}\text { Addison's disease (primary } \\
\text { adrenal insufficiency) }\end{array}$ & $\begin{array}{l}\text { Sacral } \\
\text { plasmacytoma }\end{array}$ & $\begin{array}{l}\text { Osteoporosis } \\
\text { prevention }\end{array}$ & $\begin{array}{l}\text { Osteoporosis } \\
\text { prevention }\end{array}$ & $\begin{array}{l}\text { Osteoporosis } \\
\text { prevention }\end{array}$ & $\begin{array}{l}\text { Osteoporosis } \\
\text { prevention }\end{array}$ & $\begin{array}{l}\text { Osteoporosis } \\
\text { prevention }\end{array}$ & $\begin{array}{l}\text { Polyostotic } \\
\text { fibrous } \\
\text { dysplasia, } \\
\text { bilateral } \\
\text { cleft lip } \\
\text { and palate }\end{array}$ & $\begin{array}{l}\text { Osteoporosis } \\
\text { prevention }\end{array}$ \\
\hline Age, gender & 35 , female & 77, male & 60 , female & 50 , female & 74 , female & 68 , female & 70 , female & 15 , female & 66, female \\
\hline $\begin{array}{l}\text { Medication } \\
\text { (dose rate) }\end{array}$ & $\begin{array}{l}1 \text { / week Alendronate } \\
70 \text { mg oral; } 1 \text { / day } \\
\text { hydrocortisone } 30 \text { mg, } \\
1 \text { / day fludrocortisone } \\
\text { acetate } 0.10 \text { mg, } 1 \text { / day } \\
\text { calcium with vitamin K + D } \\
1000-1500 \text { mg }\end{array}$ & $\begin{array}{l}1 / \text { month } \\
\text { Zolendronate } \\
500 \mathrm{mg} \text { iv; further } \\
\text { medication } \\
\text { (chemotherapy) }\end{array}$ & $\begin{array}{l}\text { Alendronate } \\
\text { oral, dose } \\
\text { not specified }\end{array}$ & $\begin{array}{l}\text { Alendronate } \\
\text { oral, dose not } \\
\text { specified }\end{array}$ & $\begin{array}{l}\text { Alendronate oral, } \\
\text { dose not specified; } \\
\text { drug holiday } \\
3 \text { months before } \\
\text { beginning and } \\
\text { during orthodontic } \\
\text { treatment }\end{array}$ & $\begin{array}{l}\text { Ibandronate } \\
\text { oral, dose } \\
\text { not specified }\end{array}$ & $\begin{array}{l}\text { oral, not } \\
\text { further } \\
\text { specified }\end{array}$ & $\begin{array}{l}4 \text { cycles of } \\
\text { Pamidronate } \\
\text { intravenous, } 90 \\
\text { or } 135 \mathrm{mg} \text { every } \\
5 \mathrm{months} \\
\text { ( } 45 \mathrm{mg} / \text { day, } \\
\text { over } 2 \text { to } 3 \text { days) }\end{array}$ & $\begin{array}{l}1 / \text { week } \\
\text { Alendronate } \\
70 \mathrm{mg} \text { oral }\end{array}$ \\
\hline $\begin{array}{l}\text { High/low } \\
\text { risk patient }\end{array}$ & $\begin{array}{l}\text { medium high risk (due } \\
\text { to the corticosteroid } \\
\text { medication) }\end{array}$ & high risk & low risk & low risk & low risk & low risk & low risk & high risk & low risk \\
\hline $\begin{array}{l}\text { Intake of BP during } \\
\text { orthodontic treatment? }\end{array}$ & yes, 30 months & yes & $\begin{array}{l}\text { yes, } 24 \\
\text { months }\end{array}$ & yes & no & yes & yes & no & $\begin{array}{l}\text { yes, } 6 \\
\text { months }\end{array}$ \\
\hline $\begin{array}{l}\text { How long intake } \\
\text { before orthodontic } \\
\text { treatment and all together? }\end{array}$ & $\begin{array}{l}41 \text { months before, } \\
58 \text { months all together }\end{array}$ & $\begin{array}{l}11 \text { months } \\
\text { before }\end{array}$ & $\begin{array}{l}18 \text { months } \\
\text { before, } 42 \\
\text { months } \\
\text { all together }\end{array}$ & $\begin{array}{l}6 \text { months } \\
\text { before, } 12 \\
\text { months all } \\
\text { together }\end{array}$ & 36 months before & not specified & $\begin{array}{l}10 \text { years } \\
\text { before }\end{array}$ & 2 years before & $\begin{array}{l}1 \text { month } \\
\text { before, } \\
7 \text { months } \\
\text { all together }\end{array}$ \\
\hline $\begin{array}{l}\text { Intake of BP known by } \\
\text { the orthodontists? }\end{array}$ & yes & yes & yes & no & yes & yes & yes & yes & $\begin{array}{l}\text { no, emerged } \\
\text { during } \\
\text { treatment }\end{array}$ \\
\hline $\begin{array}{l}\text { Orthodontic treatment } \\
\text { plan }\end{array}$ & $\begin{array}{l}\text { unilateral space } \\
\text { closure after } \\
\text { extraction of } \\
\text { tooth } 14 \text { and } 44\end{array}$ & $\begin{array}{l}\text { space closure } \\
\text { after extraction } \\
\text { of tooth } 42\end{array}$ & $\begin{array}{l}\text { closing } \\
\text { of right } \\
\text { posterior } \\
\text { open bite }\end{array}$ & $\begin{array}{l}\text { space closure } \\
\text { after extraction } \\
\text { of tooth } 34\end{array}$ & $\begin{array}{l}\text { space closure a } \\
\text { fter extraction } \\
\text { of tooth } 31\end{array}$ & $\begin{array}{l}\text { alignment, } \\
\text { distalization } \\
13-15 \text { with } \\
\text { skeletal } \\
\text { anchorage }\end{array}$ & $\begin{array}{l}\text { orthodontic } \\
\text { extrusion of } \\
\text { distal root of } \\
\text { teeth } 36,37\end{array}$ & $\begin{array}{l}\text { bone graft for } \\
\text { the alveolar } \\
\text { cleft to align } \\
\text { the upper } \\
\text { canines, } \\
\text { providing } \\
\text { anterior } \\
\text { crossbite }\end{array}$ & $\begin{array}{l}\text { intrusion/ } \\
\text { retrusion of } \\
\text { upper and } \\
\text { lower frontal } \\
\text { teeth using } \\
\text { skeletal } \\
\text { anchorage }\end{array}$ \\
\hline $\begin{array}{l}\text { Duration of orthodontic } \\
\text { treatment (months) }\end{array}$ & 30 & 13 (abortion) & 54 (abortion) & 19 & 14 & $\begin{array}{l}65 \text { for } \\
\text { distalization, } \\
\text { in total not } \\
\text { specified }\end{array}$ & $\begin{array}{l}7 \text { respectively } \\
5 \text { weeks }\end{array}$ & 42 & 11 \\
\hline
\end{tabular}


Table 1 Presentation of the nine reported cases of orthodontically treated patients under BP medication [9-14] (Continued)

\begin{tabular}{|c|c|c|c|c|c|c|c|c|c|}
\hline $\begin{array}{l}\text { Radiographs (end of } \\
\text { orthodontic treatment) }\end{array}$ & $\begin{array}{l}\text { radiopaque areas, } \\
\text { sclerotic lines, denser } \\
\text { bone and widened } \\
\text { periodontal ligament } \\
\text { on extraction site in } \\
\text { the mandible }\end{array}$ & $\begin{array}{l}\text { Osteonecrosis } \\
\text { in the right } \\
\text { mandible } \\
\text { (apical 44, } \\
45 \text { and dental } \\
\text { implant in } \\
\text { region 46) }\end{array}$ & $\begin{array}{l}\text { sclerotic } \\
\text { bone areas, } \\
\text { widened } \\
\text { periodontal } \\
\text { gaps }\end{array}$ & $\begin{array}{l}\text { at the } \\
\text { extraction } \\
\text { site hyper- } \\
\text { mineralized } \\
\text { areas, sclerotic } \\
\text { bone, widened } \\
\text { periodontal } \\
\text { gaps }\end{array}$ & $\begin{array}{l}\text { mandibular } \\
\text { incisors: mild } \\
\text { sclerosis and } \\
\text { periodontal } \\
\text { spaces, mild } \\
\text { root resorptions }\end{array}$ & no abnormality & $\begin{array}{l}\text { bone } \\
\text { apposition } \\
\text { in the apical } \\
\text { area }\end{array}$ & not specified & $\begin{array}{l}\text { sclerotic } \\
\text { bone areas, } \\
\text { widened } \\
\text { periodontal } \\
\text { gaps, mild } \\
\text { apical root } \\
\text { resorption } \\
\text { of maxillary } \\
\text { incisors }\end{array}$ \\
\hline Apical root resorption & none & not specified & none & not specified & yes & not specified & not specified & not specified & yes \\
\hline Tooth movement & decelerated & decelerated & decelerated & decelerated & not decelerated & not specified & not specified & not specified & $\begin{array}{l}\text { not } \\
\text { decelerated }\end{array}$ \\
\hline $\begin{array}{l}\text { Complications /noticeable } \\
\text { problems }\end{array}$ & $\begin{array}{l}\text { closing and paralyzing } \\
\text { of the roots }\end{array}$ & $\begin{array}{l}\text { osteonecrosis } \\
\text { with ulceration; } \\
\text { no bodily } \\
\text { movement, } \\
\text { only tipping } \\
\text { of the crowns }\end{array}$ & $\begin{array}{l}\text { despite } \\
\text { stopping } \\
\text { medication, } \\
\text { side effects } \\
\text { enhanced }\end{array}$ & $\begin{array}{l}\text { compromised } \\
\text { parallel roots; } \\
\text { mandibular } \\
\text { incisor } \\
\text { mobility }\end{array}$ & $\begin{array}{l}\text { no increased } \\
\text { mobility }\end{array}$ & $\begin{array}{l}\text { no complications } \\
\text { reliable to the } \\
\text { medication of BP }\end{array}$ & $\begin{array}{l}\text { no clinical } \\
\text { evidence of } \\
\text { inflammation } \\
\text { or pain, and } \\
\text { the radiograph }\end{array}$ & not specified & $\begin{array}{l}\text { higher } \\
\text { mobility of } \\
\text { the frontal } \\
\text { lower teeth }\end{array}$ \\
\hline
\end{tabular}


female patient with long-term oral BP therapy for osteoporosis. The first and second right mandibular molars were hemisected. The distal roots were orthodontically extruded for several weeks and afterwards extracted [10].

8. An alveolar bone grafting was performed on a 15year-old high-risk female patient with polyostotic fibrous dysplasia as well as a surgically-treated cleft lip and palate. BP treatment started at the age of 13 with 4 times IV pamidronate. Teeth 12 and 22 were missing, with an anterior crowding in the mandible and an anterior cross bite. It took 6 months after the graft surgery, until an obvious bone bridge at the recipient site became visible and orthodontic treatment was begun (sign of decreased healing potential of bone). Therefore, the orthodontic treatment was performed over a longer time and less aggressive. After 3.5 years of orthodontic treatment, the patient had a sufficient occlusion [11].

9. Dental implants were inserted in the lateral segments of a 66-year-old low-risk female patient and used as skeletal anchorage during orthodontic treatment. Upper and lower front teeth were in- and retruded (duration: 13 months). BP medication for osteoporosis (alendronate oral) by her general practitioner was begun without knowledge of the dental facility and stopped after 7 months because of recurrent colitis (common side effect). After treatment, the patient had enlarged PDL, sclerotic bone areas, apical root resorptions of the upper frontal teeth, and increased mobility of the mandibular incisors [12].

\section{Discussion}

The number of adult and elderly patients requiring orthodontic treatment is increasing, leading to new challenges for the provider: fundamental differences in anatomical and physiological conditions, altered periodontal situations, and different medical histories with different medications, all of which have a considerable influence on orthodontic planning and treatment [16]. In addition to the anamnesis, good communication between the dentist/ orthodontist and the general practitioner is necessary. Two of the nine reported patients were medicated with a BP without orthodontist's knowledge [12,14].

The medical history must be investigated far into the past due to the long half-life of several medications $[13,14]$. Drug holidays are controversially discussed: the long half-life of BPs in the bone (10-12 years) $[1,14]$ versus the effects of the BPs on the soft tissue including the vascular system [17].

Known risk factors for BP-ONJ development include the specific characteristics of the BP taken (type, dose, duration of use, and administration route) as well as further medications such as steroids taken in parallel [2-7]. In the analyzed articles BP-ONJ only occurred in one highrisk patient suffering from multiple myeloma who was treated with IV zoledronate and chemotherapy [13].

The analyzed cases show that the high-risk patient had the most severe side effects, but that even low-risk patients have some. The cohort study reported that low-risk BPpatients with extractions or initial spacing had higher odds of incomplete space closure, poor root parallelism and longer treatment duration [15]. The case reports/ series with extractions reported on compromised root paralleling and crown-tipping instead of bodily movement $[13,14]$.

Radiographic signs such as sclerosis of the alveolar bone and widened PDL were found [12-14]. Apical root resorptions in the anterior region were described in two of the nine patients $[12,14]$, while none were described in three cases $[13,14]$ and were not specified in four other cases [9-11,14].

The data regarding root resorption under BP influence are not consistent. One animal experimental study has observed root resorptions [18], while others have found inhibiting effects of BP on root resorption [19-23].

Regarding the common use of BP for osteoporosis in postmenopausal women, an untreated control group of rats was compared with a group of ovariectomized rats and a group of ovariectomized rats with zolendronate treatment [24]. The ovariectomized/zoledronate group showed similar results as the control group. The ovariectomized group had the highest amount of root resorptions and tooth movement [24].

Regarding the velocity of tooth movement, some of the described patients had decreased movement [13-15], but others did not $[12,14]$ or were not specified [9-11]. Several animal experimental studies have reported slowed tooth movement, partly in a dose-depending manner [19-23,25].

\section{Conclusion}

Due to the increasing number of older patients requiring orthodontic treatment, the number of patients with a medical history including BP treatment is increasing. Regarding the half-life of BPs, an intensive examination of the medical history before treatment should be obligatory. Due to the missing scientific evidence, orthodontic tooth movement in patients exposed to BPs is still unpredictable, and risk stratification should be performed. The altered bone metabolism and higher extent of side effects should be considered in treatment planning, especially in extraction cases or high-risk patients. Also, longer treatment duration, decelerated tooth movement and, in patients with initial spacing or extraction cases, incomplete space closure and poor root parallelism should be expected. 


\section{Competing interest}

The authors declare that they have no competing interest.

\section{Authors' contributions}

EK carried out the conception and design of the study. She assembled the data, conducted the analysis and interpretation of data, and drafted the manuscript. CJ is a specialist in the field Bisphosphonates and orthodontics. He was involved in conception and design of the study, also in analysis and interpretation of data, and drafting the manuscript. As a Cranio-Maxillo-Facial Surgeon and specialist in the field Bisphosphonates, CW had an indispensable contribution by conceiving and participate the design of the study, and also helped to draft the manuscript. HW, Head of the Department, conceived of the study, and participated in its design and coordination and helped to draft the manuscript. All authors read and approved the final manuscript.

\section{Author details}

'Department of Orthodontics, Medical Centre of the JohannesGutenberg-University Mainz, Augustusplatz 2, 55131, Mainz, Germany. ${ }^{2}$ Department of Cranio-Maxillo-Facial Surgery, Medical Centre of the Johannes Gutenberg-University Mainz, Augustusplatz 2, 55131, Mainz, Germany.

Received: 5 March 2013 Accepted: 25 March 2013

Published: 4 April 2013

\section{References}

1. Zahrowski Jj: Bisphosphonate treatment: an orthodontic concern calling for a proactive approach. Am J Orthod Dentofacial Orthop 2007, 131:311-20

2. Bamias A, Kastritis E, Bamia C, Moulopoulos LA, Melakopoulos I, Bozas G, Koutsoukou V, Gika D, Anagnostopoulos A, Papadimitriou C, Terpos E, Dimopoulos MA: Osteonecrosis of the jaw in cancer after treatment with bisphosphonates: incidence and risk factors. J Clin Oncol 2005, 23:8580-7.

3. Abu-ld MH, Açil Y, Gottschalk J, Kreusch T: Bisphosphonate-associated osteonecrosis of the jaw [Article in German]. Mund Kiefer Gesichtschir 2006, 10:73-81.

4. American Dental Association Council of Scientific Affairs: Dental management of patients receiving oral bisphosphonate therapy. J Am Dent Assoc 2006, 137:1144-50.

5. Grötz KA, Kreusch T: Zahnärztliche Betreuung von Patienten unter/nach Bisphosphonat-Medikation. Wissenschaftliche Stellungnahme der DGZMK 2006. Version 1.0. DZZ 60 (10); http://www.dgzmk.de/uploads/tx_ szdgzmkdocuments/Zahnaerztliche_Betreuung_von_Patienten_unternach_ Bisphosphonat-Medikation.pdf.

6. Ruggiero SL, Dodson TB, Assael LA, Landesberg R, Marx RE, Mehrotra B: American Association of Oral and Maxillofacial Surgeons Position Paper on Bisphosphonate-Related Osteonecrosis of the Jaws-2009 Update. J Oral Maxillofac Surg 2009, 67:2-12

7. Ruggiero SL: Bisphosphonate-related osteonecrosis of the jaw: an overview. Ann N Y Acad Sci 2011, 1218:38-46.

8. Walter C, Al-Nawas B, Frickhofen N, Gamm H, Beck J, Reinsch L, Blum C, Grötz KA, Wagner W: Prevalence of bisphosphonate associated osteonecrosis of the jaws in multiple myeloma patients. Head Face Med 2010, 8(6):11.

9. Vitral RW, da Silva Campos MJ, de Andrade Vitral JC, Santiago RC, Fraga MR: Orthodontic distalization with rigid plate fixation for anchorage after bone grafting and maxillary sinus lifting. Am J Orthod Dentofacial Orthop 2009, 136:109-14.

10. Kodama Y, Ogose A, Oguri Y, Ubaidus S, lizuka T, Takagi R: Alveolar bone grafting in association with polyostotic fibrous dysplasia and bisphosphonate-induced abnormal bone turnover in a bilateral cleft lip and palate patient: a case report. J Oral Maxillofac Surg 2012, 70:e500-8.

11. Smidt A, Lipovetsky-Adler M, Sharon E: Forced eruption as an alternative to tooth extraction in long-term use of oral bisphosphonates: Review, risks and technique. J Am Dent Assoc 2012, 143:1303-12.

12. Krieger E, d'Hoedt B, Scheller H, Jacobs C, Walter C, Wehrbein H: Orthodontic treatment under Bisphoshonate therapy - A case report. J Orofac Orthop 2012, 74:28-39.

13. Rinchuse DJ, Rinchuse DJ, Sosovicka MF, Robison JM, Pendleton R: Orthodontic treatment of patients using bisphosphonates: a report of 2 cases. Am J Orthod Dentofacial Orthop 2007, 131:321-6.
14. Zahrowski JJ: Optimizing orthodontic treatment in patients taking bisphosphonates for osteoporosis. Am J Orthod Dentofacial Orthop 2009, 135:361-74

15. Lotwala RB, Greenlee GM, Ott SM, Hall SH, Huang GJ: Bisphosphonates as a risk factor for adverse orthodontic outcomes: a retrospective cohort study. Am J Orthod Dentofacial Orthop. 2012, 142:625-634.

16. Bartzela T, Türp JC, Motschall E, Maltha JC: Medication effects on the rate of orthodontic tooth movement: a systematic literature review. Am J Orthod Dentofacial Orthop 2009, 135:16-26.

17. Walter C, Pabst A, Ziebart T, Klein M, Al-Nawas B: Bisphosphonates affect migration ability and cell viability of HUVEC, fibroblasts and osteoblasts in vitro. Oral Dis 2011, 17:194-9.

18. Alatli I, Hellsing E, Hammarström L: Orthodontically induced root resorption in rat molars after 1-hydroxyethylidene-1.1-bisphosphonate injection. Acta Odontol Scand 1996, 54:102-8.

19. Choi J, Baek SH, Lee Jl, Chang Yl: Effects of clodronate on early alveolar bone remodeling and root resorption related to orthodontic forces: a histomorphometric analysis. Am J Orthod Dentofacial Orthop 2010, 138(548):e1-8.

20. Fujimura Y, Kitaura H, Yoshimatsu M, Eguchi T, Kohara H, Morita Y, Yoshida $\mathrm{N}$ : Influence of bisphosphonates on orthodontic tooth movement in mice. Eur J Orthod 2009, 31:572-7.

21. Igarashi $K$, Mitani $H$, Adachi $H$, Shinoda $H$ : Anchorage and retentive effects of a bisphosphonate (AHBuBP) on tooth movements in rats. Am J Orthod Dentofacial Orthop 1994, 106:279-89.

22. Igarashi $\mathrm{K}$, Adachi $\mathrm{H}$, Mitani $\mathrm{H}$, Shinoda $\mathrm{H}$ : Inhibitory effect of the topical administration of a bisphosphonate (risedronate) on root resorption incident to orthodontic tooth movement in rats. J Dent Res 1996 75:1644-9.

23. Liu L, Igarashi K, Haruyama N, Saeki S, Shinoda H, Mitani H: Effects of local administration of clodronate on orthodontic tooth movement and root resorption in rats. Eur J Orthod 2004, 26:469-73.

24. Sirisoontorn I, Hotokezaka H, Hashimoto M, Gonzales C, Luppanapornlarp S, Darendeliler MA, Yoshida N: Orthodontic tooth movement and root resorption in ovariectomized rats treated by systemic administration of zoledronic acid. Am J Orthod Dentofacial Orthop 2012, 141:563-73.

25. Karras JC, Miller JR, Hodges JS, Beyer JP, Larson BE: Effect of alendronate on orthodontic tooth movement in rats. Am J Orthod Dentofacial Orthop 2009, 136:843-7.

doi:10.1186/1746-160X-9-10

Cite this article as: Krieger et al:: Current state of orthodontic patients under Bisphosphonate therapy. Head \& Face Medicine 2013 9:10.

\section{Submit your next manuscript to BioMed Central and take full advantage of:}

- Convenient online submission

- Thorough peer review

- No space constraints or color figure charges

- Immediate publication on acceptance

- Inclusion in PubMed, CAS, Scopus and Google Scholar

- Research which is freely available for redistribution 